\title{
Estimation of Bouguer correction density based on underground and surface gravity measurements and precise modelling of topographic effects - two case studies from Slovakia
}

\author{
Pavol ZAHOREC ${ }^{1}$, Juraj PAPČO ${ }^{2}$ \\ ${ }^{1}$ Division of Geophysics, Earth Science Institute, Slovak Academy of Sciences, \\ Banská Bystrica, Slovak Republic; e-mail: zahorec@savbb.sk \\ ${ }^{2}$ Department of Theoretical Geodesy, Faculty of Civil Engineering, \\ Slovak University of Technology, Bratislava, Slovak Republic
}

\begin{abstract}
We present a simple and straightforward method for estimating the mean density of topographic masses based on underground gravity measurements along with topography modelling. Two examples under different conditions are given, the first coming from a railway tunnel passing through a Mesozoic karst area and the second from an active coal mine situated in a Neogene sedimentary basin. Relative gravity measurements were processed and corrected by topographic effect modelling based on high-precision airborne LiDAR-derived elevation models. In addition, detailed mining tunnel gravimetric modelling based on terrestrial laser scanning data is presented. Resulted mean (bulk) densities are compared with those obtained from detailed surface gravity measurements as well as with available rock-samples density analysis.
\end{abstract}

Key words: Bouguer correction density, underground gravity, topographic effect, digital elevation model

\section{Introduction}

Calculation of Bouguer anomaly requires proper correction (reduction) density estimation. While the density of $2.67 \mathrm{~g} / \mathrm{cm}^{3}\left(1 \mathrm{~g} / \mathrm{cm}^{3}=10^{3} \mathrm{~kg} / \mathrm{m}^{3}\right)$ is generally used in global or regional studies (e.g. LaFehr, 1991; Hinze et al., 2005), in local studies the correction density should represent a real topographic rock density within the given area. The Bouguer correction density is often estimated directly from the surface gravity measurements by simple 
correlation of Bouguer anomalies with topography (Nettleton, 1939). More straightforward comparing of near topographic effect with free-air anomalies in the territory of Slovakia was recently studied in Mikuška et al. (2014, 2017).

The utility of underground gravity measurements for the density determination is well known. The gravity difference between a station at the surface and a vertically offset underground station depends on the mean density of the Earth, as well as on the density of the rock layer between the stations (e.g. Domzalski, 1955). Knowing one of these densities the other one can be determined, while the determination of the average rock layer density is generally more reliable.

In this paper we deal with gravity measurements using standard relative gravity meters, performed at the surface and in underground mines, shafts, tunnels etc. However there is a close connection with borehole gravity surveys. As Hammer (1950) wrote, his survey with standard-type gravimeter in vertical shaft was made to simulate the data, which would be obtained by a borehole gravimeter.

There is a reason why we could consider the density determination by underground gravity measurements as superior to other methods. As Hammer (1950) and Domzalski (1955) mentioned, the average (integrated) bulk density of the rocks is exactly what we need in gravity prospecting. In addition, such density can generally differ from the densities obtained from the measurements on rock samples.

Pícha (1953) published results of gravity measurements along the vertical shaft in the mine "Anna" near Př́bram in the present-day Czech Republic. And later there were other underground gravity works in the Czech Republic including experimental gravity and vertical gravity gradient measurements in the mine shaft Stonava on which we collaborated (Pospišil et al., 2013). Within the territory of the present-day Slovak Republic, however, so far we have knowledge only about unpublished pioneering underground gravity measurements in mining workings of Maar in Vybiral et al. (1990). The absence of modern underground gravity works in our country also motivated us to perform such measurements.

The issue of rock-densities in the territory of Slovakia is currently under consideration in Šamajová and Hók (2018). The authors summarized the already published density information (coming mainly from rock-samples 
analysis) and they subsequently attempted to assign a characteristic density interval to the main geologic/tectonic units present in Slovakia. As they realized, there is a very high variability of the rock densities, both laterally and vertically. Therefore, the question of proper density determination for local gravity surveys is still an open issue. In this article we present a method that enables to determine Bouguer correction density in-situ.

Currently, the LiDAR technique is often used for the generation of highresolution digital elevation models (DEM) with their wide applicability in various areas. We successfully used the LiDAR data for the vertical gravity gradient prediction (Zahorec et al., 2016), where the exact calculation of the near topographic effect is crucial. The use of terrestrial laser scanning for the near terrain correction calculation is described by Schiavone et al. (2009). Here we have used LiDAR-based elevation models, as well as terrestrial laser scan models for the precise near-zone topographic effect calculations presented in this paper.

In the first part of the article we describe the methodology for density determination. Then, two case studies are presented.

\section{Methods of rock density determination from underground gravity measurements}

The classical approach to determine mean rock density from underground gravity measurements (e.g. Hammer, 1950) is based on the following relation for gravity change along the vertical underground depth interval $\Delta H$ :

$\Delta g=(F-4 \pi \kappa \sigma) \Delta H+\Delta T$,

where $F$ is the free-air vertical gradient $(-0.3086 \mathrm{mGal} / \mathrm{m}), \kappa$ is the gravitational constant, $\sigma$ is the density and $\Delta T$ represents the variation of the terrain correction over the elevation interval $\Delta H$. The right-hand side of Eq. 1 (except of the term $\Delta T$ ) is also called Poincaré-Prey reduction. By inserting the known values the desired density can be expressed from Eq. 1 as follows:

$\sigma=3.683-11.933 \Delta g / \Delta H$ 
assuming that $\Delta g$ is corrected for topography undulations, as well as for underground excavations (shaft, mine, tunnel, etc.). The density calculated using Eq. 2 is expressed in $\mathrm{g} / \mathrm{cm}^{3}$, while the gravity is in $\mathrm{mGal}$ and the elevation in $\mathrm{m}$. Introduction of the terrain (and excavations) correction into Eq. 2 requires input density estimation. As Hammer (1950) writes, this term is so small that no appreciable error is introduced by using an assumed value of the density for it. However, it is still a source of a potential additional error. A method presented below overcomes this complication.

Another source of potential error in density determination arises from anomalous vertical gradients associated to local or regional gravity anomalies. The presence of anomalous bodies can be estimated from Bouguer anomaly maps or from additional gravity measurements (Hammer, 1950). Because of the known geological situation in our study areas, we do not expect local anomalous bodies, which could potentially cause anomalous vertical gradients.

Unlike the classical method, the presented approach is simpler and more straightforward. After correcting the measured gravity difference between the vertically separated surface and underground gravity stations using the normal VGG (again, presuming there is no abnormal VGG caused by anomalous sources), we can assign the resultant gravity difference $\Delta g$ (which in fact equals to the difference in the free-air anomalies) to the difference in the effect of the topography (meaning the gravitational effect of the masses between the topo-surface and the zero level, the so-called Near Topographic Effect - NTE), taking into consideration the effect of the underground objects (tunnel, mine). Therefore the density value can be simply obtained by dividing the $\Delta g$ by the $\Delta$ NTE, while NTE is calculated for the density of $+1.0 \mathrm{~g} / \mathrm{cm}^{3}$ and the tunnel $/$ mine effect for the density of $-1.0 \mathrm{~g} / \mathrm{cm}^{3}$. It should be noted that the situation is a little complicated if the measuring points lie below seal level, we will discuss this briefly later.

The NTE is calculated using the proprietary software Toposk (Zahorec et al., 2017a). The program enables to calculate very precise topographic effect at arbitrary point location, e.g. above or below the topographic surface, the latter being a special case of underground gravity stations. The NTE is considered up to the standard distance of $166.7 \mathrm{~km}$, while the calculated area is divided into the following zones: inner zone up to $250 \mathrm{~m}$ from the calculation point, intermediate zone $250-5240 \mathrm{~m}$ and outer zones from 5.24 
up to $166.7 \mathrm{~km}$. The inner and intermediate zones play dominant roles, so they must be considered more carefully. We have used high-precision DEMs derived from LiDAR data within the inner zone.

The effects of underground objects (tunnel, mine) were calculated using two approaches. First we tried to use again the Toposk software and DEMs prepared from terrestrial laser scanning data. As the Toposk program requires input elevation models in grid format, the excavated object must be defined using two complementary grids. The effect of the object is calculated simply as a difference between the topographic effects of the top and the bottom topo-surface (grid), see an example in Fig. 1. We have successfully used this approach in the case of railway tunnel (case study I), as we had a detailed laser scan model available over the whole tunnel (performed by Amberg Tunnel Scan system). On the other hand, as we did not have such model available from the mine (case study II), we tried to perform laser scanning using the total station Trimble SX10. But as we have realized, this task has become very difficult due to the presence of a dense fog inside the mine. Therefore we were not able to model the mining corridor up to a sufficient distance around all measurement stations employing laser scan data. Thus we utilized Potent software (Potent, 2010) for modelling using a polygonal prism approach, while the cross section of the mining corridor was taken from the closest laser scan data (Fig. 2) or from hand-held laser distance meter measurements.

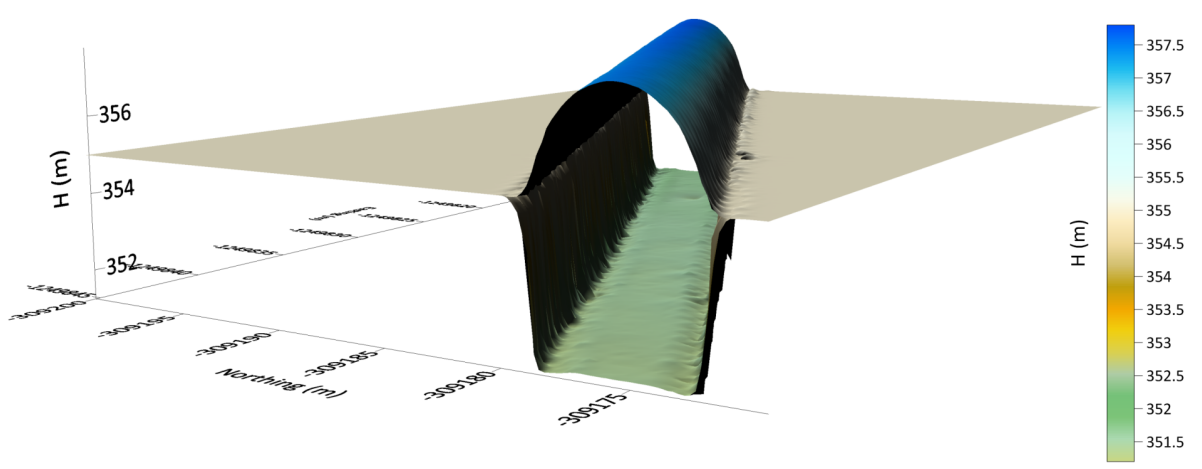

Fig. 1. An example of underground object (tunnel) modelled by two topo-grids. Gravitational effect of the tunnel is calculated using Toposk software simply as a difference between topographic effects defined by particular topo-surfaces. 

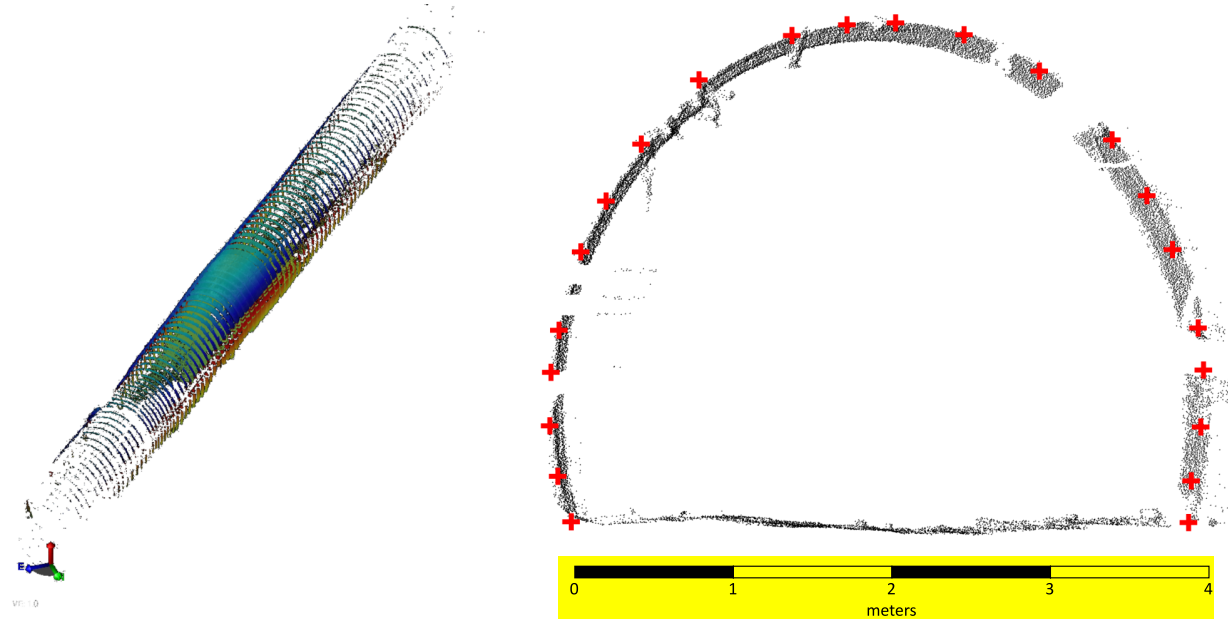

Fig. 2. 3D view of in-situ laser scanning data from the mine (case study II, left). A cross section of the mine (right) was defined by the point cloud (black) taken from the closest laser scan data. Red crosses were used as vertices of polygonal prism approximating the tunnel and modelled using the Potent software.

\section{Case study I - railway tunnel Soroška}

The underground gravity measurements were performed in the Jablonovský railway tunnel passing Mesozoic karst rocks in the Slovenský kras area (Fig. 3). Measurement stations in the tunnel were chosen at the crossing points of the tunnel with the former detailed surface gravity profiles (Fig. 4), while the vertical distance between surface gravity stations and the tunnel was approximately $200 \mathrm{~m}$. Our goal was to validate the value of the correction density used in Bouguer anomaly calculation. Since the gravity survey mainly covers the area of Mesozoic rocks (limestones, marl slates, etc., see Fig. 4), we assumed that their density should not differ much from the value of $2.67 \mathrm{~g} / \mathrm{cm}^{3}$. Detailed density analysis along the surface gravity profiles based on the proportionality between free-air anomalies and the NTE (Fig. 5) confirmed this assumption, leading to the value of about $2.66 \mathrm{~g} / \mathrm{cm}^{3}$ (Mikuška et al., 2017). On the other hand, the density analysis from drilling rock-samples showed a little higher values of volume densities, specifically about $2.7 \mathrm{~g} / \mathrm{cm}^{3}$ (Zahorec et al., 2017b). We assume that this 


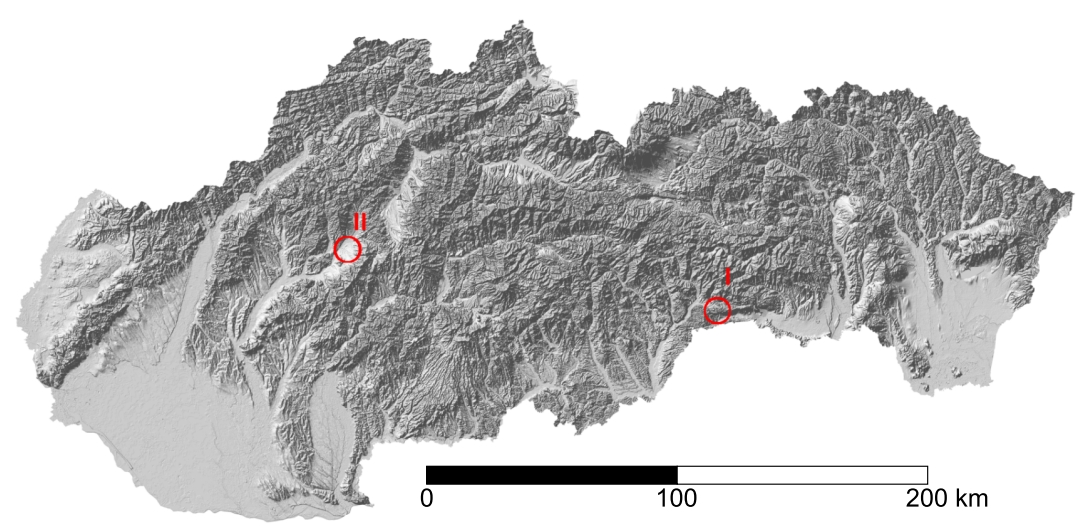

Fig. 3. Relief map of Slovakia showing position of the two studied localities with underground gravity measurements. Case study I is located in the hilly area composed of Mesozoic units of the Slovenský kras, case study II is located in the Neogene sedimentary rocks of the Hornonitrianska kotlina basin.

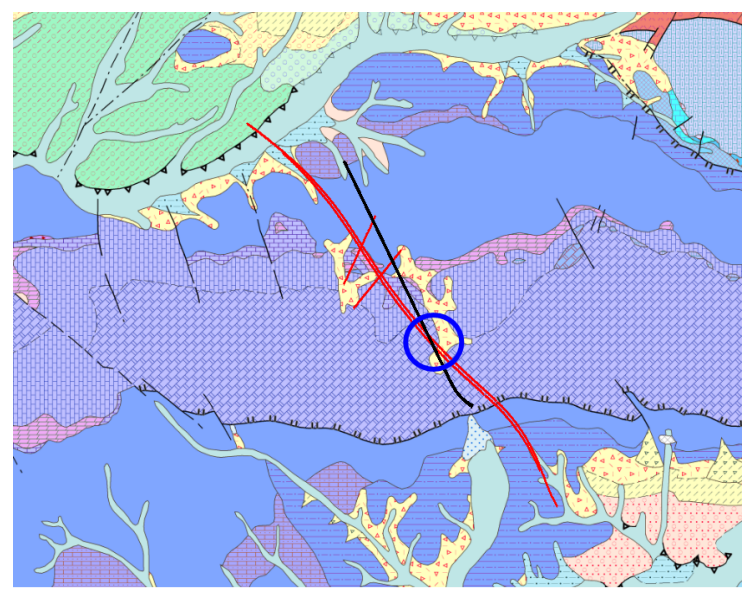

Fig. 4. Detailed situation of the case study I (blue circle). Underground gravity measurements were performed at the crossing points of railway tunnel (black line) with two parallel surface gravity profiles (longer red lines). The vicinity of the utilized measured stations is built by Steinalm and Wetterstein limestones. Geological background is taken from Káčer et al. (2005).

difference could be due to a significant karstification of the limestones.

Positions of the underground gravity stations were determined by terrestrial measurements using the total station Leica MS50. Horizontal and 


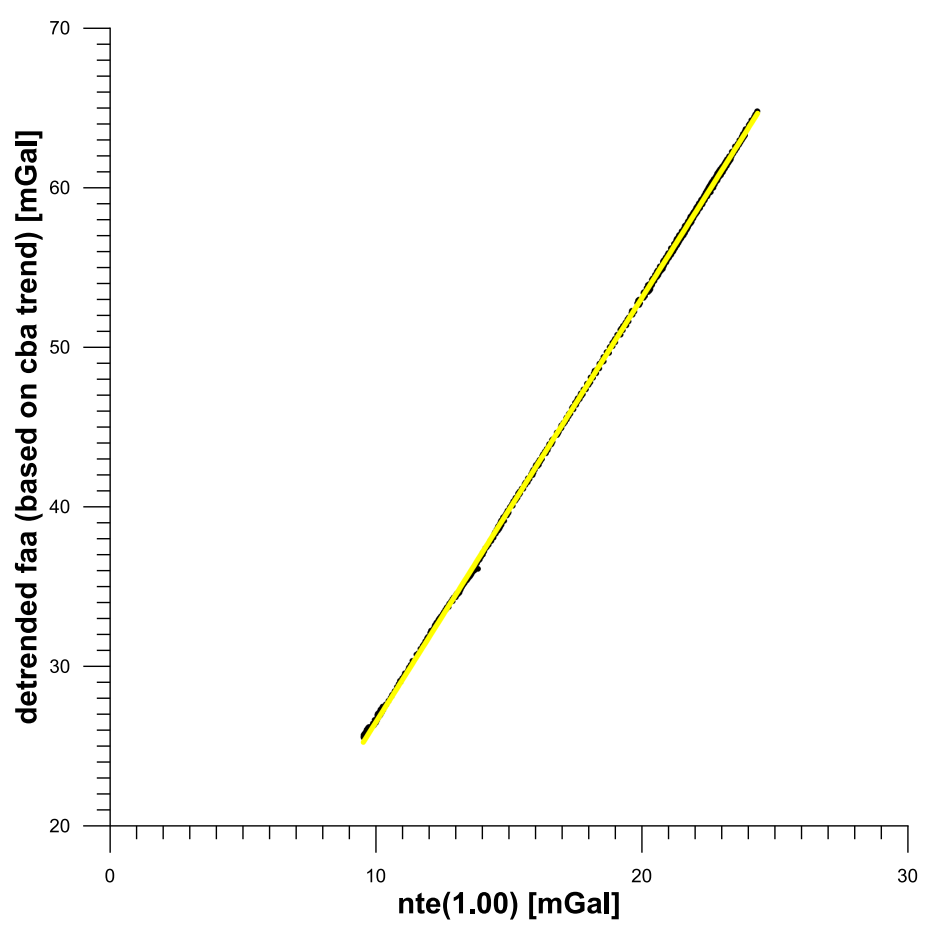

Fig. 5. Graph showing an almost linear dependence of the free-air anomalies "faa" (after elimination of a linear regional trend taken from the complete Bouguer anomaly "cba") on the near topographic effect "nte" calculated for density of $1.0 \mathrm{~g} / \mathrm{cm}^{3}$ (Mikuška et al., 2017). The linear regression coefficient of approximately 2.66 should represent the estimated density of the topographic rocks in $\mathrm{g} / \mathrm{cm}^{3}$ units.

vertical accuracy of the measurements are better than $0.03 \mathrm{~m}$. The stations inside the tunnel were set to be vertically aligned with the surface gravity points within a few centimeters in their horizontal positions. Besides the four main stations (exactly projected from the surface gravity profiles points), several side points were also measured for comparison. Gravity values at each station were measured using CG-5 gravity meter, while the same instrument and the same methodology were used for the surface gravity measurements. The gravity measurement error was estimated at \pm 10 $\mu \mathrm{Gal}$ for both surface and underground measurements.

In addition, vertical gradients of gravity (VGG) were measured at two underground stations to appraise methodically the possibility of the den- 
sity determination from the VGG measurements. The VGG measurements were performed in a tower mode using relative gravity meter CG-5 and a geodetic tripod. Gravity was measured in A-B-A-B-A repeated mode at two height levels (A and $\mathrm{B}$ ) with gravity meter sensor approximately $0.25 \mathrm{~m}$ and $1.2 \mathrm{~m}$ above the ground, respectively. The exact height of the gravity meter sensor above the ground was measured using high-precision hand-held laser distance meter. The measurement at one station had to be interrupted due to a passing train. The measurement error at this station was estimated to $\pm 7 \mu \mathrm{Gal}$, while it was $\pm 2 \mu \mathrm{Gal}$ at the other station.

As mentioned above, the measured positions of gravity stations and their gravity values have to be corrected for the normal gradient $(-0.3086$ $\mathrm{mGal} / \mathrm{m}$ ), and then for the NTE, including the effect of the tunnel. For this purpose we used the airborne LiDAR-based DEM with resolution of $0.5 \mathrm{~m}$ and estimated vertical accuracy of approximately $\pm 0.15 \mathrm{~m}$ (Zahorec et al., 2017b). In addition, the available terrestrial laser scan model of the tunnel (performed by Amberg GRP 5000) was used for exact calculation of the effect of the tunnel. We also calculated the effect of the tunnel on the surface gravity points. Since this effect reaches values of only several $\mu \mathrm{Gal}$, it can be neglected. Tables 1 and 2 summarize the mentioned effects and the calculated density values for pairs of the surface/underground gravity stations, as well as underground VGG points. The results will be discussed

Table 1. Summarized measured differences $\Delta H, \Delta g$, calculated free-air gradient effect (FAGE), near topographic effect (density of $+1.0 \mathrm{~g} / \mathrm{cm}^{3}$ ), gravitational effect of the tunnel (density of $-1.0 \mathrm{~g} / \mathrm{cm}^{3}$ ) and calculated densities for a set of pairs of surface/underground gravity stations within the case study I.

\begin{tabular}{|l|c|c|c|c|c|c|c|}
\hline $\begin{array}{c}\text { Under- } \\
\text { ground } \\
\text { station }\end{array}$ & $\begin{array}{c}\Delta H \\
(\mathrm{~m})\end{array}$ & $\begin{array}{c}\Delta g \\
(\mathrm{mGal})\end{array}$ & $\begin{array}{c}\text { FAGE } \\
(\mathrm{mGal})\end{array}$ & $\begin{array}{c}\text { NTE } \\
\text { surface } \\
(\mathrm{mGal})\end{array}$ & $\begin{array}{c}\text { NTE } \\
\text { tunnel } \\
(\mathrm{mGal})\end{array}$ & $\begin{array}{c}\text { Tunnel } \\
\text { effect } \\
(\mathrm{mGal})\end{array}$ & $\begin{array}{c}\text { Density } \\
\left(\mathrm{g} / \mathrm{cm}^{3}\right)\end{array}$ \\
\hline 13691 & 207.075 & -22.367 & -63.903 & 22.714 & 7.004 & 0.101 & $\mathbf{2 . 6 6 1}$ \\
\hline 136911 & 207.007 & -22.434 & -63.882 & 22.714 & 7.013 & 0.118 & $\mathbf{2 . 6 6 0}$ \\
\hline 13701 & 204.717 & -22.010 & -63.176 & 22.624 & 7.027 & 0.118 & $\mathbf{2 . 6 5 9}$ \\
\hline 23801 & 175.836 & -16.914 & -54.263 & 21.476 & 7.315 & 0.109 & $\mathbf{2 . 6 5 8}$ \\
\hline 238011 & 175.818 & -16.933 & -54.257 & 21.476 & 7.319 & 0.118 & $\mathbf{2 . 6 5 9}$ \\
\hline 23805 & 175.85 & -16.984 & -54.267 & 21.476 & 7.332 & 0.118 & $\mathbf{2 . 6 5 8}$ \\
\hline 23811 & 173.096 & -16.480 & -53.417 & 21.361 & 7.342 & 0.110 & $\mathbf{2 . 6 5 6}$ \\
\hline 238111 & 173.103 & -16.490 & -53.420 & 21.361 & 7.341 & 0.118 & $\mathbf{2 . 6 5 6}$ \\
\hline 23805 & 173.076 & -16.453 & -53.411 & 21.361 & 7.332 & 0.118 & $\mathbf{2 . 6 5 7}$ \\
\hline
\end{tabular}


Table 2. Summarized measured differences $\Delta H, \Delta g$, calculated free-air gradient effect (FAGE), near topographic effect (density of $+1.0 \mathrm{~g} / \mathrm{cm}^{3}$ ), gravitational effect of the tunnel (density of $-1.0 \mathrm{~g} / \mathrm{cm}^{3}$ ) and calculated densities for two gravity stations with measured vertical gradients. A stands for lower measurement level, B stands for upper level. Note that the resulting values may be subject to rounding errors.

\begin{tabular}{|l|c|c|c|c|c|c|c|c|}
\hline $\begin{array}{c}\text { VGG } \\
\text { station }\end{array}$ & $\begin{array}{c}\Delta H \\
(\mathrm{~m})\end{array}$ & $\begin{array}{c}\Delta g \\
(\mathrm{mGal})\end{array}$ & $\begin{array}{c}\text { FAGE } \\
(\mathrm{mGal})\end{array}$ & $\begin{array}{c}\text { NTE A } \\
(\mathrm{mGal})\end{array}$ & $\begin{array}{c}\text { NTE B } \\
(\mathrm{mGal})\end{array}$ & $\begin{array}{c}\text { Tunnel } \\
\text { effect A } \\
(\mathrm{mGal})\end{array}$ & $\begin{array}{c}\text { Tunnel } \\
\text { effect B } \\
(\mathrm{mGal})\end{array}$ & $\begin{array}{c}\text { Density } \\
\left(\mathrm{g} / \mathrm{cm}^{3}\right)\end{array}$ \\
\hline 23805 & 0.949 & -0.205 & -0.293 & 7.353 & 7.431 & 0.118 & 0.071 & $\mathbf{2 . 8 1 7}$ \\
\hline 136911 & 0.947 & -0.211 & -0.292 & 7.034 & 7.110 & 0.118 & 0.072 & $\mathbf{2 . 7 2 3}$ \\
\hline
\end{tabular}

later.

For verification we have also compared our straightforward approach of density determination with the classical method described above (Eq. 2). Table 3 summarizes calculated effects and resultant densities. The terrain correction (for the "assumed" density of $2.67 \mathrm{~g} / \mathrm{cm}^{3}$ ) was calculated as difference between the gravitational effect of truncated spherical layer with the thickness equal to the elevation of a particular surface gravity station and the calculated NTE. We note that the this way calculated terrain correction has a "standard" meaning for surface gravity points, but this is not the case for underground gravity points. It is interesting to see that in the case of

Table 3. Summarized terrain corrections (assumed density of $2.67 \mathrm{~g} / \mathrm{cm}^{3}$ ), gravitational effects of the tunnel (assumed density of $-2.67 \mathrm{~g} / \mathrm{cm}^{3}$ ) and calculated densities for a classic method applied to a set of pairs of surface/underground gravity stations (measured values of $\Delta H$ and $\Delta g$ are shown in Table 1). Densities calculated for the case when terrain correction and tunnel effect are not included are shown in the last column.

\begin{tabular}{|l|c|c|c|c|c|}
\hline $\begin{array}{l}\text { Under- } \\
\text { ground } \\
\text { station }\end{array}$ & $\begin{array}{c}\text { Terrain } \\
\text { correction } \\
\text { surface } \\
\text { (mGal) }\end{array}$ & $\begin{array}{c}\text { Terrain } \\
\text { correction } \\
\text { tunnel } \\
\text { (mGal) }\end{array}$ & $\begin{array}{c}\text { Tunnel } \\
\text { effect } \\
(\mathrm{mGal})\end{array}$ & $\begin{array}{c}\text { Density } \\
\left(\mathrm{g} / \mathrm{cm}^{3}\right)\end{array}$ & $\begin{array}{c}\text { Density } \\
(\text { no terrain } \\
\text { correction }) \\
\left(\mathrm{g} / \mathrm{cm}^{3}\right)\end{array}$ \\
\hline 13691 & 2.706 & -1.629 & 0.269 & $\mathbf{2 . 6 5 9}$ & $\mathbf{2 . 3 9 3}$ \\
\hline 136911 & 2.706 & -1.638 & 0.315 & $\mathbf{2 . 6 5 8}$ & $\mathbf{2 . 3 8 9}$ \\
\hline 13701 & 2.680 & -1.430 & 0.316 & $\mathbf{2 . 6 5 8}$ & $\mathbf{2 . 3 9 9}$ \\
\hline 23801 & 2.402 & 0.907 & 0.290 & $\mathbf{2 . 6 5 6}$ & $\mathbf{2 . 5 3 4}$ \\
\hline 238011 & 2.402 & 0.902 & 0.315 & $\mathbf{2 . 6 5 7}$ & $\mathbf{2 . 5 3 3}$ \\
\hline 23805 & 2.402 & 0.861 & 0.315 & $\mathbf{2 . 6 5 6}$ & $\mathbf{2 . 5 2 9}$ \\
\hline 23811 & 2.396 & 1.133 & 0.294 & $\mathbf{2 . 6 5 4}$ & $\mathbf{2 . 5 4 6}$ \\
\hline 238111 & 2.396 & 1.136 & 0.314 & $\mathbf{2 . 6 5 4}$ & $\mathbf{2 . 5 4 5}$ \\
\hline 23805 & 2.396 & 1.167 & 0.315 & $\mathbf{2 . 6 5 5}$ & $\mathbf{2 . 5 4 8}$ \\
\hline
\end{tabular}


underground stations, the terrain correction can reach negative as well as positive values (see third column in Table 3). That is in agreement with previous works, e.g. by Algermissen (1961).

Because our goal was numerical comparison of the methods, we calculated terrain correction up to the same distance of $166.7 \mathrm{~km}$, however, $\mathrm{Al}$ germissen (1961) for instance calculated his correction for topography up to $2615 \mathrm{~m}$ ( 8578 feet). The last column in Table 3 shows density values calculated for the specific case in which terrain correction and tunnel effect are not included in the calculation at all. Since this locality is hilly, the differences are significant this time.

\section{Case study II - active coal mine Ban̆a Nováky}

This case study is a typical example of an active subsidence associated with mining activities. Currently the area is intensively studied within the framework of the scientific project VEGA 1/0462/16. Monitored gravity profiles are located above the border of the mining area (Fig. 6). Unlike in case study I, a small number of the monitored gravity points, as well as the flatness of the area, do not allow a reliable density analysis based on the surface gravity profiles. Moreover, we do not have rock-sample density analysis available from this area. Therefore we performed underground gravity measurements (and corresponding surface measurements) in accessible mining corridors, in order to prove the density determination methodology and to better estimate the Bouguer correction density for the gravity profiles.

Positions of five underground gravity stations (Fig. 6) were determined by terrestrial measurements using the total station Trimble SX10. Horizontal and vertical accuracies of the measurements are better than $0.05 \mathrm{~m}$. The corresponding surface gravity stations were targeted using GNSS measurement in the Real Time Kinematic Mode (RTK) with SKPOS service. The surface stations were set to be vertically aligned with the underground gravity stations within a few centimeters in horizontal position, while the vertical distance between surface/underground stations ranged from 146 to $200 \mathrm{~m}$.

Gravity value at each station was measured using two CG-5 gravity meters. After the data processing we found out that there were systematic 


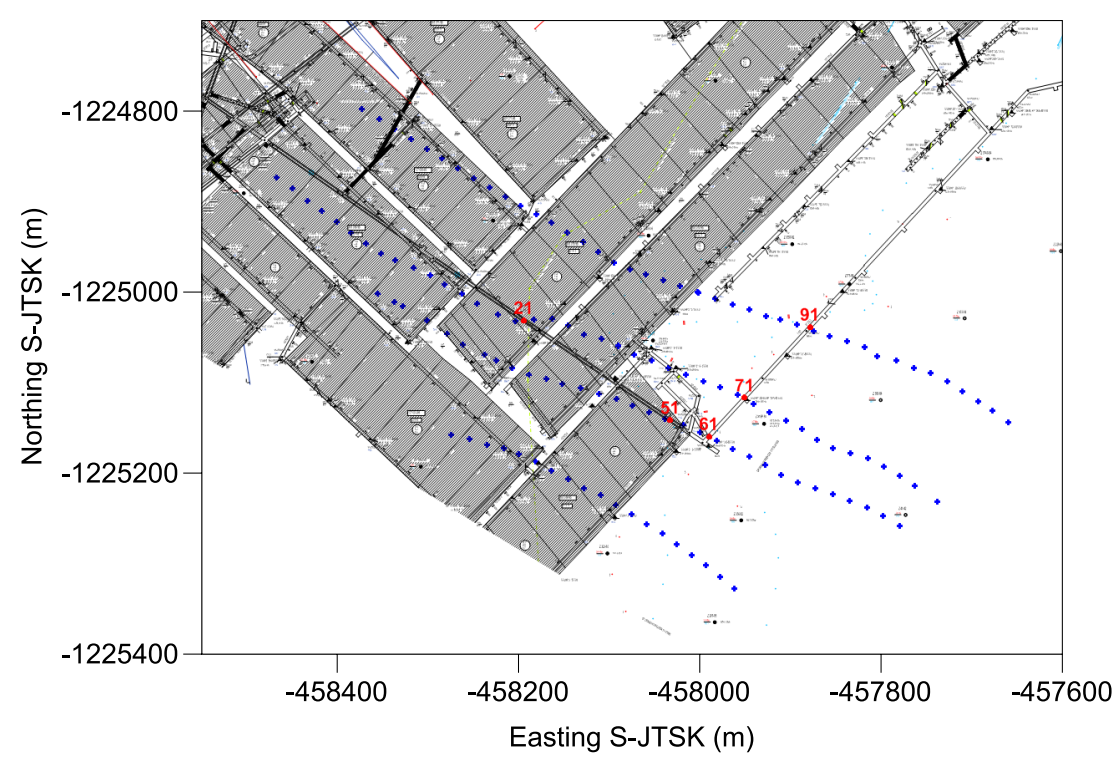

Fig. 6. Situation of the case study II. Red numbered circles represent pairs of surface/underground gravity stations. Blue crosses are surface monitoring gravity profiles. Shaded background indicates excavated coal beds. Underground measurements were carried out in mining corridors, which are also visible.

differences between the gravity values from the individual gravity meters (average difference of $40 \mu \mathrm{Gal}$ ). We assumed that this could be caused by incorrect calibration factors of gravity meters. Therefore we subsequently performed re-calibration of both gravity meters at vertical calibration line with gravity range of $200 \mathrm{mGal}$ in the High Tatra Mountains. After the reprocessing, average difference between gravity values from both gravity meters decreased from 40 to $15 \mu \mathrm{Gal}$. It is even more interesting to note that McCulloh (1965) already pointed out the errors in density determination associated with bad calibration factors.

Besides positional measurements, we also used total station Trimble SX10 for laser scanning to map the shape and dimensions of the mining corridors in order to calculate their effect using the Toposk program. However, it was not easily performed because of the presence of dense fog. We got sufficient scans (at least $20 \mathrm{~m}$ around the gravity station) only at two stations. Therefore we had to model the gravitational effect of the corri- 
dors also in another way, by means of polygonal prism approximation using the software Potent (Fig. 7), while a cross-section of the prism was defined on the basis of laser scan data (Fig. 2). We compared both approaches at common points. Both methods provided practically the same results. The advantage of the modelling via Potent software is that we can extend the length of the corridor arbitrarily. On the other hand, proved by our modelling tests, extending the corridor length beyond $20 \mathrm{~m}$ on both sides brings only negligible improvement of its gravitational effect.

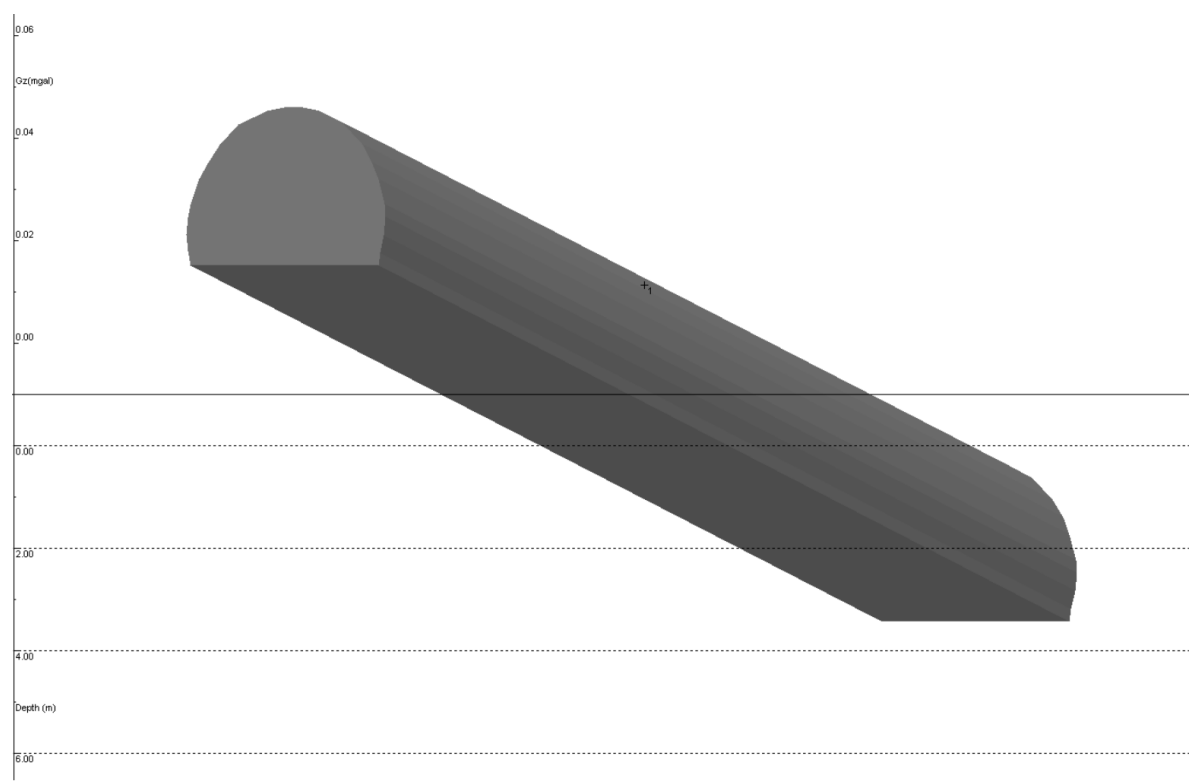

Fig. 7. Mining corridor modelled in Potent software (picture is taken from software interface).

The NTE was calculated in the same way as described above, using highprecision airborne LiDAR-based DEM, although this time with resolution of $1 \mathrm{~m}$ and estimated vertical accuracy of approximately $\pm 0.15 \mathrm{~m}$. The calculated effects are summarized in Table 4. The average value of the determined density is about $2.04 \mathrm{~g} / \mathrm{cm}^{3}$. According to Šamajová and Hók (2018), densities in Neogene basins should range from 2.0 to $2.2 \mathrm{~g} / \mathrm{cm}^{3}$ to a depth of $1000 \mathrm{~m}$. Nevertheless, Stránska et al. (1986) state the value of $1.92 \mathrm{~g} / \mathrm{cm}^{3}$ for Neogene formation in Hornonitrianska kotlina basin. 
Table 4. Summarized measured differences $\Delta H, \Delta g$, calculated free-air gradient effect (FAGE), near topographic effects (density of $+1.0 \mathrm{~g} / \mathrm{cm}^{3}$ ), gravitational effects of the mining corridor (density of $-1.0 \mathrm{~g} / \mathrm{cm}^{3}$ ) and calculated densities for a set of pairs of surface/underground gravity stations in case study II.

\begin{tabular}{|c|c|c|c|c|c|c|c|}
\hline Station & $\begin{array}{c}\Delta H \\
(\mathrm{~m})\end{array}$ & $\begin{array}{c}\Delta g \\
(\mathrm{mGal})\end{array}$ & $\begin{array}{c}\text { FAGE } \\
(\mathrm{mGal})\end{array}$ & $\begin{array}{c}\text { NTE } \\
\text { surface } \\
(\mathrm{mGal})\end{array}$ & $\begin{array}{c}\text { NTE } \\
\text { mine } \\
(\mathrm{mGal})\end{array}$ & $\begin{array}{c}\text { Mine } \\
\text { effect } \\
(\mathrm{mGal})\end{array}$ & $\begin{array}{c}\text { Density } \\
\left(\mathrm{g} / \mathrm{cm}^{3}\right)\end{array}$ \\
\hline 21 & 200.252 & -27.242 & -61.798 & 11.447 & -5.765 & 0.052 & $\mathbf{2 . 0 1 4}$ \\
\hline 51 & 147.994 & -20.077 & -45.671 & 11.718 & -0.956 & 0.053 & $\mathbf{2 . 0 2 8}$ \\
\hline 61 & 146.02 & -19.747 & -45.062 & 11.831 & -0.639 & 0.064 & $\mathbf{2 . 0 4 1}$ \\
\hline 71 & 147.958 & -19.913 & -45.660 & 11.885 & -0.719 & 0.066 & $\mathbf{2 . 0 5 4}$ \\
\hline 91 & 150.308 & -20.015 & -46.385 & 11.914 & -0.884 & 0.060 & $\mathbf{2 . 0 7 0}$ \\
\hline
\end{tabular}

\section{Discussion}

Results from case study I (Table 1) show that the surface/underground gravity measurements give reliable density value of approximately $2.66 \mathrm{~g} / \mathrm{cm}^{3}$, which is in perfect agreement with the density analysis of profile surface measurements (Fig. 5). This density value also supports the assumption about the lower mean density due to the karstification of the rocks, in contrast to the laboratory rock-samples densities. There is yet another interesting fact arising from Table 1 . We can sort the measured stations into two groups according to their position below the surface profiles. The first group consists of the first three points (numbered starting with the numeral 1). This group of points is about $300 \mathrm{~m}$ away from the second group along the tunnel. When considering these groups separately, we can see a weakly decreasing trend of the calculated density. The average density value in the first group of points is $2.660 \mathrm{~g} / \mathrm{cm}^{3}$, while in the second group it is $2.657 \mathrm{~g} / \mathrm{cm}^{3}$. The difference is really small, but it could represent a change in lithology, or in the intensity of karstification.

On the contrary, underground VGG measurements (Table 2) show controversial results. The estimated densities differ from each other, as well as from previous values. This could have several reasons. First reason could be the expected sensitivity of the method to the measurement error. Table 2 shows that the greatest impact on the mutual density differences between two stations arises from the measured gravity differences. Better density estimation would require more accurate VGG measurements. Yet 
there is also another issue to consider. The VGG measurement, unlike the surface/underground measurement, is much more sensitive to local density conditions around the VGG station. This makes the method principally less suitable for Bouguer correction density estimation, even if the maximum measurement accuracy is achieved.

Comparing densities calculated using the presented method (Table 1) with the ones calculated using the classical method (Table 3, fifth column), we found only very small differences. This is because we used the same approach for the calculation of the NTE and the terrain correction and also because the "assumed" density of $2.67 \mathrm{~g} / \mathrm{cm}^{3}$ (used for terrain correction in the classical method) is very close to the true density. However, if the assumed density differed greatly from the real one, the result would be much more affected. This fact is highlighted when the terrain corrections in the classical method are completely omitted (Table 3, last column). Since the topography in this area is hilly, the error in density estimation increases considerably.

Densities determined in the case study II (Table 4) show a significantly increasing trend with increasing number of stations. We assume that there could actually be a connection with the positions of stations, since the stations with lower numbers are distributed in the area of extracted coal beds, while those with higher numbers are outside the exploited area (see Fig. 6).

One more remark is needed. The presented method is easy to implement in cases where underground stations are still at positive heights (i.e. above sea level), which was the case for both presented sites. On the other hand, if underground stations would have negative heights (i.e. below sea level), the method would require modifying elevation models, because usually DEMs are defined only for positive elevations.

\section{Conclusions}

The presented straightforward method for Bouguer correction density determination based on underground as well as surface gravity measurements was used in two case studies with different conditions. The density of $2.66 \mathrm{~g} / \mathrm{cm}^{3}$ was calculated for a Mesozoic karst area in the Slovenský kras and the mean density of $2.04 \mathrm{~g} / \mathrm{cm}^{3}$ was calculated for the Neogene rocks of the Hornonitrianska kotlina basin. The determined densities are in accordance with 
the published values typical for both sites. At the first site a slightly lower density was determined compared to the results of rock-samples analysis, probably due to karstification. In addition, the calculated densities show systematic change in horizontal direction, suggesting the possible change in the geological structure depending on the position of extracted coal beds (case study II), as well as the intensity of karstification (case study I). Comparison with the "classical" method (based on Poincaré-Prey reduction including terrain corrections) shows consistency, if the same approach is used for the topographic effect and the terrain correction calculation. On the contrary, if the terrain corrections are omitted or calculated with incorrectly assumed density, the possible error from the classical approach will arise. Therefore the presented method is not only simpler but also more reliable than the classical method.

Acknowledgements. This work was supported by the VEGA grant agency under project No. 1/0462/16. The authors express their thanks to Marián Plakinger (Hornonitrianske bane Prievidza), Matej Oros (Geotronics Slovakia), Branislav Hinca, Vladimír Minarech (REMING CONSULT) and Martin Salva (Železnice Slovenskej republiky) for assistance with the realization of the measurements.

\section{References}

Algermissen S. T., 1961: Underground and surface gravity survey, Leadwood, Missouri. Geophysics, 26, 158-168.

Domzalski W., 1955: Relative determination of the density of surface rocks and the mean density of the Earth from vertical gravity measurements. Geophysical prospecting, 3, 212-227.

Hammer S., 1950: Density determination by underground gravity measurements. Geophysics, 15, 637-652.

Hinze W. J., Aiken C., Brozena J., Coakley B., Dater D., Flanagan G., Forsberg R., Hildebrand T., Keller G. R., Kellogg J., Kucks R., Li X., Mainville A., Morin R., Pilkington M., Plouff D., Ravat D., Roman D., Urrutia-Fucugauchi J., Véronneau M., Webring M, Winester D., 2005, New standards for reducing gravity data: The North American gravity database. Geophysics, 70, J25-J32.

Káčer Š., Antalík M., Lexa J., Zvara I., Fritzmann R., Vlachovič J., Bystrická G., Brodianska M., Potfaj M., Madarás J., Nagy A., Maglaj J., Ivanička J., Gross P., Rakús M., Vozárová A., Buček S., Boorová D., Šimon L., Mello J., Polák M., Bezák V., Hók J., Teták F., Konečný V., Kučera M., Žec B., Elečko M., Hraško L., Kováčik M., Pristaš J., 2005: Digital geological map of Slovak Republic in the scale 1:50 000. Final report, State Geological Institute of Dionýz Štúr, Bratislava. 
LaFehr T. R., 1991: Standardization in gravity reduction. Geophysics, 56, 1170-1178.

McCulloh T. H., 1965: A confirmation by gravity measurements of an underground density profile based on core densities. Geophysics, 30, 1108-1132.

Mikuška J., Marušiak I., Zahorec P., Papčo J., Pašteka R., Bielik M., 2014: Some Interesting Facts about Correlation between Gravity Anomalies and Heights with Implications towards the Bouguer Correction Density Estimation. AGU FALL MEETING, San Francisco, 15-19 December 2014 (poster).

Mikuška J., Zahorec P., Papčo J., Karcol R., Marušiak I., 2017: Surface rock density interpretation from detailed gravity measurements based on free-air anomalies and near topographic effects in a terrain with sufficient relative relief. XII Slovak Geophysical Conference, 28-29 September, 2017, Bratislava (oral, abstract).

Nettleton L. L., 1939: Determination of density for reduction of gravimeter observations. Geophysics, 4, 176-183.

Pícha J., 1953: Underground gravity acceleration in the mine "Anna" in Březové hory Mountain. Travaux géophysiques, 9, Geophysical Institute ČSAV, Praha, 119-129.

Pospíšil L., Černota P., Mikuška J., Volařík T., Pospíšil J., Papčo J., Zahorec P., 2013: Experimental gravity and vertical gravity gradient measurements in mine shaft Stonava (Sto-Su-1), Ostrava-Karviná district, Czech Republic. Workshop "Tatry 2013 - New pieces of knowledge based on realizing and interpreting geodetic observations", 21-22 November, 2013, Štrbské pleso, High Tatras, Slovakia (oral). ISBN 978-80-89626-01-4.

Potent v.4.11.06, 2010: User guide. Manuscript, Geophysical Software Solutions Pty. Ltd., Gungahlin, Australia.

Schiavone D., Capolongo D., Loddo M., 2009: Near-station topographic masses correction for high-accuracy gravimetric prospecting. Geophysical Prospecting 57, 739-752.

Stránska M., Ondra P., Husák L', Hanák J., 1986: Density map of the West Carpathians within the territory of Czechoslovakia. Final report, Geofyzika s.e. Brno, branch Bratislava, (unpublished; in Slovak).

Šamajová L., Hók J., 2018: Densities of rock formations of the Western Carpathians on the territory of Slovakia. Geological Studies, Reports, 132, State Geological Institute of Dionýz Štúr, Bratislava. (in press; in Slovak).

Vybíral V., Jančí J., Maar S., 1990: Nízke Tatry Mountains - Jasenie Au, W. Geophysical survey - III phase (1989-1990). Final report, Geofyzika s.e. Brno, branch Bratislava (unpublished; in Slovak).

Zahorec P., Vajda P., Papčo J., Sainz-Maza S., Pereda de Pablo J., 2016: Prediction of vertical gradient of gravity and its significanse for volcano monitoring - example from Teide volcano. Contributions to Geophysics and Geodesy, 46, 3, 203-220.

Zahorec P., Marušiak I., Mikuška J., Pašteka R., Papčo J., 2017a: Numerical Calculation of Terrain Correction Within the Boguer Anomaly Evaluation (Program Toposk), chapter 5, pp. 79-92, In book: Roman Pašteka, Ján Mikuška and Bruno Meurers (Eds.): Understanding the Bouguer Anomaly: A Gravimetry Puzzle, Elsevier, ISBN 978-0-12-812913-5, doi : 10.1016/B978-0-12-812913-5.00006-3. 
Zahorec P., Papčo J., Vajda P., Szabó S., 2017b: Realization of geophysical survey gravimetry within the project "Highway R2 Rožňava - Jablonov nad Turňou". Technical report, Slovak Academy of Sciences, Earth Science Institute, Banská Bystrica (unpublished; in Slovak). 